\title{
Identifikasi Bakteri Coliform pada Air Kobokan di Rumah Makan Kelurahan Andalas Kecamatan Padang Timur
}

\author{
Ervan Arditya Kusuma1, Roslaili Rasyid², Endrinaldi ${ }^{3}$
}

\begin{abstract}
Abstrak
Air kobokan merupakan media untuk cuci tangan yang banyak digunakan di rumah makan di Kota Padang. Diare adalah penyakit yang ditularkan melalui air yang terkontaminasi oleh bakteri. Angka perkiraan kasus diare di Padang Timur merupakan yang tertinggi di Kota Padang. Tujuan penelitian ini adalah untuk mengetahui kualitas mikrobiologi air kobokan di rumah makan di Kelurahan Andalas Kecamatan Padang Timur. Sebanyak 21 sampel yang diambil dan dibagi sesuai dengan sumber airnya yaitu 12 sumber air PDAM dan 9 sumber air sumur bor. Penelitian ini dibagi dalam dua tahap, tahap pertama: pengambilan sampel dan observasi faktor yang mempengaruhi kontaminasi. Kedua: uji bakteriologi dengan metode Most Propable Number (MPN) yang meliputi uji penduga, uji konfirmasi dan uji lengkap.Seluruh sampel air kobokan mengandung bakteri coliform. Sebagian besar sampel tidak memenuhi syarat mikrobiologis sesuai dengan PERMENKES no 46 tahun 1990 dan hanya satu sampel yang berasal dari air PDAM memenuhi syarat mikrobiologis. Sampel yang berasal dari PDAM didapatkan 4 yang mengandung E.coli dan dari sumber sumur bor didapatkan 3 sampel mengandung E.coli dan lainnya mengandung bakteri lain seperti Klebsiella, Enterobacter dan Pseudomonas. Hal ini dipengaruhi oleh banyak faktor seperti kebersihan wadah, lokasi rumah makan dan lokasi sumur bor.
\end{abstract}

Kata kunci: air kobokan, most propable number (MPN).

\section{Abstract}

Water is the common use for hand washing in restaurant in Padang city. The research was conducted at restaurant in Andalas, East Padang. Diarrhea is a disease transmitted through water contaminated by bacteria. Morbidity of diarrhea in East Padang is the highest in Padang. The objective of this study was to identify microbiological quality of water for cleaning hand at Restaurant in Andalas sub-district, East Padang district. Total 21 sampels were taken and divided according to the water source is 12 by PDAM and 9 from dug well. This research implemented in two steps: taking the water for cleaning hand sample and also observing factor affecting contamination of the water for cleaning hand, then bacteriologi inspection using Most Propable Number (MPN) methods to presumptive test, confirmation test and complementary test. All of them sampel containing coliform bacteria. Almost of the sample unqualified according PERMENKES no 46 tahun 1990 and just only one sample from PDAM source qualified with microbiological requirement. Four sample from PDAM source contain E.coli bacteria and three sample from dug well contain E.coli bacteria too and the others contain another bacteria like Klebsiella, Enterobacter and Pseudomonas. It can be cause many factor like hygiene of container, restaurant location and dug well location.

Keywords: water for cleaning hand, most propable number (MPN)

Affiliasi penulis: 1. Pendidikan Dokter FK UNAND (Fakultas Kedokteran Universitas Andalas Padang), 2. Bagian Mikrobiologi FK UNAND, 3. Bagian Kimia FK UNAND

Korespondensi: Ervan Arditya Kusuma, E-mail

:ervan.ard@gmail.com Telp: 082391855955

\section{PENDAHULUAN}

Waterborne disease adalah penyakit yang penularannya melalui air yang terkontaminasi bakteri patogen yang ditularkan kepada manusia melalui 
mulut atau sistem pencernaan. ${ }^{1}$ Waterborne disease merupakan salah satu masalah kesehatan masyarakat yang utama terutama di negara berkembang. Waterborne disease merupakan penyebab utama morbiditas dan mortalitas pada semua kelompok umur terutama pada anak dibawah lima tahun. ${ }^{2}$ Salah satu penyakit dari waterborne disease yang paling sering adalah diare. Diare adalah penyebab kematian kedua pada anak dibawah usia lima tahun sekitar $15 \%$ pada tahun 2008. ${ }^{3}$ Diare merupakan penyakit infeksi yang disebabkan oleh virus maupun bakteri. Diare adalah buang air besar dengan tinja berbentuk cair atau setengah cair dan kandungan air tinja lebih banyak dari biasanya lebih dari 200 gram atau $200 \mathrm{ml} / 24 \mathrm{jam}$ dan frekuensinya lebih dari 3 kali per hari. ${ }^{4}$ Menurut World Health Organization (WHO) dan The United Nations Children's Fund (UNICEF)pada tahun 2006 angka kejadian diare sekitar dua milliar kasus per tahunnya dan sekitar 1,9 juta anak-anak dibawah usia lima tahun meninggal setiap tahunnya dan sebagian besar terjadi di negara berkembang. ${ }^{5}$

Berdasarkan laporan Departemen Kesehatan Republik Indonesia (Depkes RI) angka morbiditas dan mortalitas diare masih tinggi yaitu pada tahun 2010 411/1000 penduduk. ${ }^{6}$ Kota Padang berdasarkan Riset Kesehatan Dasar (RISKESDAS) pada tahun 2011 diare menempati urutan ke sembilan dengan angka kejadian 10.282 kasus dan pada Kecamatan Padang Timur terdapat perkiraan kasus sebanyak 3.188 kasus. ${ }^{7}$ Bakteri coliform pada umumnya tidak terdapat di air bersih, hanya terdapat di kotoran manusia atau hewan. Jika terdapat coliform maka hal ini menunjukkan kontaminasi yang bersifat patogen dan bisa menimbulkan penyakit seperti diare. ${ }^{8}$ Selain itu diare juga dapat dipengaruhi oleh penggunaan air bersih serta kebiasaan mencuci tangan dengan sabun. ${ }^{9}$ Mencuci tangan dengan sabun dan air mengalir dapat menurunkan sepertiga kejadian diare. ${ }^{10}$ Kebiasaan mencuci tangan dengan air kobokan di rumah makan sebelum makan tidak sesuai dengan aturan Keputusan Menteri Kesehatan Republik Indonesia Nomor 1098/MENKES/SK/VII/ 2003 tentang Persyaratan Hygiene Sanitasi Rumah Makan dan Restoran. ${ }^{11}$

Berdasarkan ketidak sesuaian ketersediaan air kobokan dirumah makan di Kelurahan Andalas
Kecamatan Padang Timur dengan peraturan Menteri Kesehatan maka dilakukan pengujian untuk mengetahui ada tidaknya kuman patogen dalam air kobokan

\section{METODE}

Ini adalah penelitian deskriptif laboratorium yang dilakukan di Laboratorium Mikrobiologi Fakultas Kedokteran Universitas Andalas Padang dari Januari - Juli 2013. Sampel penelitian ini adalah air kobokan di rumah makan Kelurahan Andalas Kecamatan Padang Timur sebanyak 21 sampel dan dibedakan berdasarkan sumber air yaitu air PDAM dan air sumur bor. Sampel dimasukkan ke dalam botol steril kemudian dilakukkan pemeriksaan mikrobiologi dengan menggunakan metode Most Probable Number (MPN) yang terdiri dari presumptive test dengan menggunakan media Lactose Broth (LB) dengan metode 3 tabung, confirmative test dengan menggunakan media Brillian Green Lactose Broth (BGLB) dan complete test dengan menggunakan media endo agar.

\section{HASIL}

Penelitian dilakukan dengan mengambil sampel air kobokan di rumah makan di Kelurahan Andalas Kecamatan Padang Timur pada dari April - Mei 2013. Sampel yang diambil sebanyak 21 rumah makan, didapatkan 12 menggunakan sumber air yang berasal dari PDAM dan 9 berasal dari sumur bor.

Tabel 1. Hasil presumptive test air kobokan yang berasal dari air PDAM

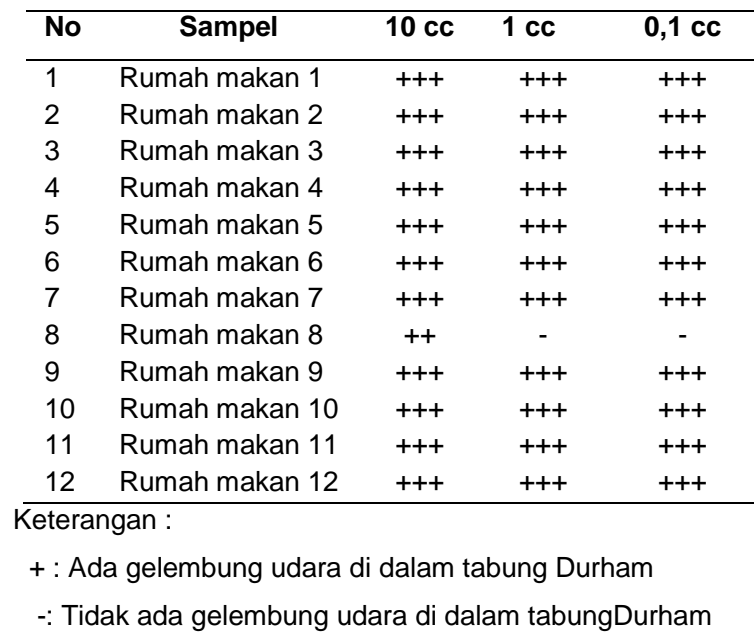

Berdasarkan Tabel 1 dan 2 didapatkan bahwa jumlah tabung yang positif sebanyak 182 tabung dari 
total tabung reaksi yang digunakan. Sampel menunjukkan hasil positif dikarenakan timbul gas pada tabung durham. Sampel positif dilanjutkan ke confirmative test.

Tabel 2. Hasil Presumptive test air kobokan yang berasal dari sumur bor

\begin{tabular}{ccccc}
\hline No & Sampel & 10 Cc & 1Cc & 0,1 Cc \\
\hline 1 & Rumah Makan 1 & +++ & +++ & +++ \\
2 & Rumah Makan 2 & +++ & +++ & +++ \\
3 & Rumah Makan 3 & +++ & +++ & +++ \\
4 & Rumah Makan 4 & +++ & +++ & +++ \\
5 & Rumah Makan 5 & +++ & +++ & +++ \\
6 & Rumah Makan 6 & +++ & +++ & +++ \\
7 & Rumah Makan 7 & +++ & +++ & +++ \\
8 & Rumah Makan 8 & +++ & +++ & +++ \\
9 & Rumah Makan 9 & +++ & +++ & +++ \\
\hline Keterangan : & & &
\end{tabular}

Keterangan :

+ : Ada gelembung udara di dalam tabung Durham

-: Tidak ada gelembung udara di dalam tabung Durham

Pada Tabel 3 dan 4 didapatkan besaran nilai indeks MPN. Nilai indeks MPN menunjukkan jumlah bakteri coliform yang terdapat dalam $100 \mathrm{ml}$ sampel air kobokan. Nilai indeks MPN pada hampir semua sampel sama yaitu $>2400 / 100 \mathrm{ml}$ air kecuali pada sampel no 8 pada air kobokan yang bersumber dari air PDAM yang menunjukkan nilai 9 pada indeks MPN. Hasil positif kemudian dilanjutkan ke complete test (uji lengkap).

Tabel 3. Hasil confirmative test air kobokan yangberasal dari air PDAM

\begin{tabular}{|c|c|c|c|c|c|}
\hline No & Sampel & $10 \mathrm{cc}$ & $1 \mathrm{cc}$ & $0,1 \mathrm{cc}$ & $\begin{array}{l}\text { Indeks } \\
\text { MPN }\end{array}$ \\
\hline 1 & Rumah makan 1 & +++ & +++ & +++ & $>2400$ \\
\hline 2 & Rumah makan 2 & +++ & +++ & +++ & $>2400$ \\
\hline 3 & Rumah makan 3 & +++ & +++ & +++ & $>2400$ \\
\hline 4 & Rumah makan 4 & +++ & +++ & +++ & $>2400$ \\
\hline 5 & Rumah makan 5 & +++ & +++ & +++ & $>2400$ \\
\hline 6 & Rumah makan 6 & +++ & +++ & +++ & $>2400$ \\
\hline 7 & Rumah makan 7 & +++ & +++ & +++ & $>2400$ \\
\hline 8 & Rumah makan 8 & ++ & - & - & 9 \\
\hline 9 & Rumah makan 9 & +++ & +++ & +++ & $>2400$ \\
\hline 10 & Rumah makan 10 & +++ & +++ & +++ & $>2400$ \\
\hline 11 & Rumah makan 11 & +++ & +++ & +++ & $>2400$ \\
\hline 12 & Rumah makan 12 & +++ & +++ & +++ & $>2400$ \\
\hline
\end{tabular}

Keterangan :

+ : Ada gelembung udara di dalam tabung Durham

-: Tidak ada gelembung udara di dalam tabung Durham
Tabel 4. Hasil confirmative test air kobokan yang berasal dari sumur bor

\begin{tabular}{cccccc}
\hline No & Sampel & 10 cc & 1cc & 0,1 cc & $\begin{array}{c}\text { Indeks } \\
\text { MPN }\end{array}$ \\
\hline 1 & Rumah Makan 1 & +++ & +++ & +++ & $>2400$ \\
2 & Rumah Makan 2 & +++ & +++ & +++ & $>2400$ \\
3 & Rumah Makan 3 & +++ & +++ & +++ & $>2400$ \\
4 & Rumah Makan 4 & +++ & +++ & +++ & $>2400$ \\
5 & Rumah Makan 5 & +++ & +++ & +++ & $>2400$ \\
6 & Rumah Makan 6 & +++ & +++ & +++ & $>2400$ \\
7 & Rumah Makan 7 & +++ & +++ & +++ & $>2400$ \\
8 & Rumah Makan 8 & +++ & +++ & +++ & $>2400$ \\
9 & Rumah Makan 9 & +++ & +++ & +++ & $>2400$ \\
\hline
\end{tabular}

Keterangan :

+ : Ada gelembung udara di dalam tabung Durham

-: Tidak ada gelembung udara di dalam tabung Durham

Pada Tabel 5 dan 6 menggambarkan bakteri yang terdapat pada air kobokan sepert: bakteri E.coli, Klebsiella, Enterobacter dan Pseudo-monas.

Tabel 5. Hasil complete test air kobokan yang berasal dari air PDAM

\begin{tabular}{lll}
\hline No & Sampel & Hasil \\
\hline 1 & Rumah Makan 1 & Enterobacter \\
2 & Rumah Makan 2 & Enterobacter dan \\
& & Pseudomonas \\
3 & Rumah Makan 3 & Klebsiella \\
4 & Rumah Makan 4 & Klebsiella \\
5 & Rumah Makan 5 & Klebsiella dan \\
& & Pseudomonas \\
6 & Rumah Makan 6 & E.coli \\
7 & Rumah Makan 7 & Pseudomonas \\
8 & Rumah Makan 8 & E.coli \\
9 & Rumah Makan 9 & E.coli \\
10 & Rumah Makan 10 & E.coli \\
11 & Rumah Makan 11 & Pseudomonas \\
12 & Rumah Makan 12 & Enterobacter \\
\hline
\end{tabular}

Hasil penelitian yang didapatkan hampir seluruhnya menunjukkan indeks MPN yang tinggi yaitu $>2400$ per $100 \mathrm{ml}$ air dan hanya 1 sampel yaitu no 8 pada air PDAM yang menunjukkan nilai indeks MPN yang rendah dan memenuhi syarat bakteriologis dengan nilai indeks MPN 9. Nilai MPN ini jauh melebihi dari standar yang ditetapkan pemerintah yaitu Peraturan Menteri Kesehatan no 416 Tahun 1990 
tentang persyaratan kualitas air bersih adalah tidak boleh mengandung bakteri golongan coliform lebih dari $50 / 100$ cc air. ${ }^{12}$

Tabel 6. Hasil complete test air kobokan yang berasal dari air sumur bor

\begin{tabular}{lll}
\hline No & Sampel & Hasil \\
\hline 1 & Rumah Makan 1 & Klebsiella \\
2 & Rumah Makan 2 & Enterobacter \\
3 & Rumah Makan 3 & E.coli \\
4 & Rumah Makan 4 & Klebsiella \\
5 & Rumah Makan 5 & Enterobacter \\
6 & Rumah Makan 6 & Klebsiella \\
7 & Rumah Makan 7 & Pseudomonas \\
8 & Rumah Makan 8 & E.coli \\
9 & Rumah Makan 9 & E.coli \\
\hline
\end{tabular}

\section{PEMBAHASAN}

Nilai indeks MPN yang rendah pada sampel air kobokan yang berasal dari rumah makan No 9 yang sumber airnya berasal dari PDAM. Hal ini memungkinkan karena pedagang mungkin sudah menerapkan hygiene dan sanitasi yang baik. Sedangkan untuk sampel yang lain masih belum memenuhi syarat bakteriologis.

Hasil pemeriksaan pada seluruh sampel didapatkan 4 sampel dari sumber air PDAM dan 3 sampel dari sumber air sumur bor yang menunjukkan hasil positif mengandung E. coli. Keberadaan E.coli dan bakteri coliform umumnya normal berada di feses manusia dan hewan. Keberadaannya dapat menandakan telah terjadi kontaminasi tinja pada air dan memungkinkan terdapat bakteri patogen lain di dalam air. Pada sampel lainnya terdapat bakteri lain yaitu Klebsiella, Enterobacter dan Pseudomonas. Keberadaan Klebsiella dan Pseudomonas pada sampel mungkin terjadi kontaminasi dari tanah, karena bakteri ini banyak di tanah, sedangkan Enterobacter menandakan ada kontaminasi dari feses, karena bakteri terdapat di saluran cerna.

Temuan ini hampir sama dengan penelitian sebelumnya yang pernah dilakukan di Kecamatan Kota Timur dan Kecamatan Dumbo Raya, Gorontalo pada tahun 2012. Pada penelitian tersebut didapatkan $76 \%$ rumah makan memenuhi syarat kesehatan dan $24 \%$ yang tidak memenuhi syarat. ${ }^{13}$ Kontaminasi yang terjadi dapat berasal dari kurang menjaga kebersihannya terutama kebersihan di tempat pencucian alat dan bahan-bahan makanan, penggunaan wadah air kobokan yang berulang tanpa dicuci dengan bersih, serta lokasi rumah makan yang dekat dengan sumber pencemaran seperti tempat pembuangan sampah.

Total 21 sampel air kobokan yang berasal dari rumah makan di Kelurahan Andalas yang diteliti, didapatkan hasil positif pada seluruh sampel dan mayoritas memiliki nilai indeks MPN yang tinggi. Hal ini menandakan bahwa air kobokan yang digunakan tidak memenuhi kriteria bakteriologis untuk air bersih sesuai dengan PERMENKES no 416 tahun 1990.12 Hygiene dan sanitasi rumah makan yang belum sehat dan bersih memiliki peran penting dalam pencemaran bakteri di air kobokan. Selain itu kebiasaan mencuci tangan dengan air kobokan sudah tidak dianjurkan, sebaiknya mencuci tangan dengan air mengalir dan sabun.

\section{KESIMPULAN}

Kualitas air kobokan pada rumah makan di Kelurahan Andalas, Padang Timur berdasarkan hasil pemeriksaan laboratorium menunjukkan sampel air yang berasal dari air PDAM hampir seluruhnya tidak memenuhi syarat kualitas air dan air yang berasal dari sumur bor seluruhnya tidak memenuhi syarat mikrobiologis sesuai dengan PERMENKES NO.416 tahun 1990.

Terdapat bakteri coliform pada air kobokan di rumah makan di Kelurahan Andalas, Padang Timur baik sumber air yang berasal dari PDAM maupun dari sumur bor.

\section{DAFTAR PUSTAKA}

1. Chandra B. Pengantar kesehatan lingkungan. Jakarta:EGC; 2005.

2. Demena M, Workie A, Tadesse E, Mohammed S, Gebru T. Waterborne disease for the ethiopian health center team. Modul. Ethiopia: Haramaya University; 2003. hIm 12-3.

3. World Health Organization. Waterborne disease is world's leading killer. USA: WHO; 2013.

4. Simadibrata, Daldiyono. Diare akut. Dalam: Buku Ajar Ilmu Penyakit Dalam Jilid 1. Edisi ke-5. Jakarta: Interna Publishing; 2009. hlm 548-9. 
5. World Gastroenterology Organisation. Acute diarrhea in adults and children: a global perspective. 2012 (diunduh 20 Januari 2013). Tersedia dari: URL: HYPERLINK http://www.world gastroenterology.org/assets/export/userfiles/Acute \%20Diarrhea long FINAL 120604.pdf

6. Departemen Kesehatan RI. Situasi diare di indonesia. buletin jendela data dan informasi kesehatan. Vol.2. Jakarta: Kementrian Kesehatan RI; 2011.

7. Dinas Kesehatan Kota Padang. Laporan tahunan kesehatan tahun 2011. Padang; 2012.

8. Josephine A, Morello PA, Mizel GHE. Laboratory manual and workbook in microbiology applications to patient care. Edisi ke-7. New York: Mc Grawhill,Inc; 2003.

9. Amaliah S. Hubungan sanitasi lingkungan dan faktor budaya dengan kejadian diare pada anak dan balita di Desa Toriyo Kecamatan Bendosari
Kabupaten Sukoharjo. 2010 (diunduh 20 Januari 2013). Tersedia dari: URL: HYPERLINK http://jurnal.unimus.ac.id/index.php/psn12012010/ $\underline{\text { article/view/776 }}$

10. The United Nations Children's Fund. Common water and sanitation related. Geneva: UNICEF; 2003.

11. Departemen Kesehatan RI. Peraturan Menteri Kesehatan No 1098 Tahun 2003 tentang persyaratan hygiene sanitasi rumah makan dan restoran. 2010.

12. Departemen Kesehatan RI. Peraturan Menteri Kesehatan No.416 Tahun 1990 tentang syaratsyarat dan pengawasan kualitas air. 2009.

13. Blongkod, Fitriani.R. Studi hygiene sanitasi rumah makan di kecamatan kota timur dan kecamatan Dumbo Raya Kota Gorontalo 2012 (skripsi). Gorontalo: Universitas Negeri Gorontalo; 2012. 